\title{
ANALYSIS OF INCOME GROWTH AND EVALUATION OF ECONOMIC DEVELOPMENT IN CENTRAL SULAWESI, INDONESIA
}

\author{
Tope Patta \\ Faculty of Economics and Business, University of Tadulako, Palu, Indonesia \\ E-mail: pattatope@yahoo.com
}

\begin{abstract}
This study aimed to determine the GRDP per capita growth rate in Central Sulawesi to community income distribution. The analysis tool used was regression statistics using data trends over the previous eight years period. The research result indicated that the GRDP per capita growth in Central Sulawesi within 2011-2018 period did not exhibit significant income distribution improvement. The high GRDP per capita growth rate is benefited by high-income individuals. On the other hand, people at the lower income levels could not benefit from economic development. Therefore, the community empowerment program and infrastructure development should be considered as main agenda of development in Central Sulawesi. It is conducted to ensure all community groups could benefit from access to economic opportunities and public services.
\end{abstract}

\section{KEY WORDS}

Growth, income, equity, economy, Central Sulawesi.

Economic development is a process of increasing total income and income per capita by taking into account population growth and fundamental changes in the economic structure of a country. Income distribution is an effort carried out by the government to ensure community income is distributed equally. Equitable distribution of income does not mean each citizen obtain the same amount of income. However, they are given the same opportunity to gain access to economic resources as an endeavor to improve living standard (Novianto and Sudarsono 2018). The national and regional economic development goals are high economic growth and GDP per capita, as well as equitable distribution of development outcomes to improve community welfare.

High GRDP per capita growth rates in Central Sulawesi without equitable development create weak regional economic structures, as it relies on exploiting natural resources. This condition generates inequality of access to education. Low levels of education would generate low productivity and income (Sari, 2018). The gap in the level of education causes a greater level of income gap (Timothy, 2014). Equitable development is a necessity to ensure every community member of Central Sulawesi may benefit from regional development.

Inequality of income in Central Sulawesi society would cause social unrest which ultimately disrupts regional stability. Therefore the process of economic development in Central Sulawesi analyzed two points of view, especially in analyzing the relationship between the growths of regional per capita GRDP with equitable development in recent years. This research endeavored to determine a relationship between the growths of GRDP per capita with equitable development. It also endeavors to determine whether the regional development generated qualified GRDP growth, especially in terms of equity, because the growth of regional GRDP per capita has always been higher than the growth of national GRDP per capita in recent years. The increasing aggregate demand of the people of Central Sulawesi indicated economic characteristics such as; the relative increase in people's purchasing power, the relative increase in investment interest, and the declining capacity of unemployed individuals in various sectors. 


\section{LITERATURE REVIEW}

According to Schumpeter (1912), economic growth occurs in line with innovation from entrepreneurs. In this case, innovation is the application of new knowledge and technology in the business field. Innovation influences in various manners: the introduction of new technology encourages higher profits and imitation of innovation. The imitation of new technology would increase production output. The economic actors are seen as creatures that continue to innovate in advancing the economic cycle itself. However, innovation is full of instability. Kuznets (1955) stated that economic growth is an increase in the long-term ability of a country in providing various types of economic goods in large quantities to its population. According to Baran (1962), economic growth can also be interpreted as a per capita increase of the material output of goods produced within a certain time interval.

Despite the mainstream economic framework and countries policies adopting political growth, there is various criticisms against it. One of the sharpest criticisms on the concept of economic growth is from the Commission on the Measurement of Economic Performance and Social Progress, led by Joseph Stiglitz, Amartya Sen, and Jean-Paul Fitoussi (Stiglitz, 2009). The commission, formed by former French President Nicholas Sarkozy in early 2008, criticized the Gross Domestic Product (GDP) as a measure of increasing economic activity most used by several countries possess issues. GDP is a manner to measure "market production" instead of economic welfare. Therefore, measuring GDP and its growth as an indicator of economic welfare is very ambiguous and produce erroneous indications on society condition. Therefore it would lead to incorrect policymaking. According to these individuals, the equal distribution of income between individuals in society is also important to consider in development process. The measure of income distribution or the measure of income sharing imbalance is a quantitative measure that describes the equitable distribution of income generated by various economic actors.

The discussion of inequality in income distribution was initially dominated by Kuznetz hypothesis. Using cross-country (cross-section) data and surveys/observations in each sector (time series), Kusnetz found a relationship between income distribution and inverted U-per capita income levels. This result was interpreted as the evolution of income distribution in the process of transition from a rural economy to an urban or economic economy. At the beginning of the development process, inequality in income distribution increased as a result of the process of urbanization and industrialization. At the end of the development process, inequality decreases. It would occur at the time urban areas sectors are capable to absorb the majority of the workforce from rural areas (the agricultural sector) or when agriculture production and income generation is smaller.

Based on the framework that underlies the "Kuznetz hypothesis", there are several questions that always arise. Whether there is a long-term positive correlation between the level of income (growth rate) and the level of equity in the distribution of income or a correlation between the level of income per capita and the amount of income disparity after several years period. Whether there is a relationship between increasing average income per capita (which reflects the higher level of economic development) and the level of income distribution in the form of an "inverted U curve", as stated in Kuznetz's hypothesis. Whether it is possible inequality will increase again (U curve appears reversed, second) or not.

Based on empirical studies assessing Kusnetz's hypothesis, using macro data from several countries, most of these studies supported the Kuznets hypothesis. However, several studies reject the Kusnetz' hypothesis. Deininger and Squire (1996) do not exhibit a systematic relationship between growth income and distribution patterns. Despite this hypothesis was accepted, the majority of the studies exhibited that the positive relationship between growth and equity over the long term is only evident for the group of advanced industrial countries (groups of countries with high-income levels). The research result must be responded critically because the cross-section study approach has several weaknesses. The approach does not include the influence of income distribution development in each country individually. For example, the level of the income distribution (as measured by the Gini index) in the previous period (period $t=0$ ) greatly influences the current level of income 
distribution or income growth inequality $(t=1)$ in a country.

It is not surprising that there is no standard theory that can be used to analyze the relationship between income and distribution. It is wrong to assume that this theory applies to all countries. One theory can usually only be used to analyze in certain terms and certain communities. Therefore, this hypothesis was assessed in the context of the Central Sulawesi region. It determined whether the growth of per capita income (GRDP per capita) goes hand in hand with the distribution of income between individuals in the community as has been widely discussed by experts over the years.

\section{METHODS OF RESEARCH}

The study used secondary data in the form of time series of GRDP per capita growth (percent) and Gini coefficients in Central Sulawesi from 2011 to 2018. The data were obtained from the Central Statistics Agency of Central Sulawesi. Analysis tool used was Regression equation models (Rencher and Schaalje, 2008).

$Y_{1}=A X_{i}^{B i} E$ transformed in the form of $\mathrm{Ln}$ into a linear form which is described as follows:

$$
\operatorname{Ln} Y=\beta 0+\beta_{1} \operatorname{Ln} X_{1}+\varepsilon
$$

Where: $Y=$ Central Sulawesi Province GRDP per capita growth; $X_{1}=$ Central Sulawesi Province Gini Coefficient; $\beta o=$ Constant; $\beta_{1}=$ Regression coefficient, as well as elasticity; $\varepsilon=$ Epsilon.

Calculations used simple regression analysis model formulas. Data processing was conducted through computer facilities utilizing statistical data processing program or SPSS (Statistical Product and Service Solution) v.19 in professional manner.

\section{RESULTS AND DISCUSSION}

Recent GRDP per capita growth in Central Sulawesi has exhibited very positive results. This is indicated by constant positive growth in the last seven years. In general GRDP per capita growth in Central Sulawesi is always positive and tends to be higher than the growth of Indonesia's GRDP per capita. Central Sulawesi GRDP per capita growth based on Constant Price (ADHK) 2011 was 7.92 percent. It exhibited a slight decrease in 2012 at 7.63 percent. It increased to 7.75 percent in 2013. GRDP per capita of Central Sulawesi in 2014 increased by 3.43 percent as a result of government regulations that prohibit the export of raw goods especially mining raw materials sector. In 2015, the GRDP per capita growth in Central Sulawesi increased to 13.67 percent due to increased exports from the nickel industry in Morowali Regency. In 2016, the GRDP per capita growth in Central Sulawesi declined to 8.27 percent. Regardless, it was the highest economic growth in Indonesia. In 2017, GRDP per capita growth in Central Sulawesi declined to 5.55 percent as a result of declining nickel exports from Morowali Regency to China. The declining GRDP growth per capita continued in 2018. It declined to 4.65 percent. It was caused by natural disasters that struck Palu City, Sigi Regency, Donggala Regency, and Parigi Moutong Regency on September 18th, 2018 (https://sulteng.bps.go.id).

Based on the Central Statistics Agency (BPS) of Central Sulawesi Province (https://sulteng.bps.go.id), the Central Sulawesi Gini ratio in 2011 was 0.352 points. The condition increased to 0.374 points in 2012. It continued to increase at 0.389 in 2013. The results of the publication of the BPS data exhibited that there has been an increase in indivivual income inequality in Central Sulawesi during the 2011-2013 period. However, this coefficient value was suppressed in 2014 by 0.362 points. It increased in 2015 up to 0.374 . In 2016, the Gini coefficient was reduced to 0.362 points. In 2017, it continued to decrease up to 0.355 points. In 2018 , the Gini coefficient returned to 0.346 points. 


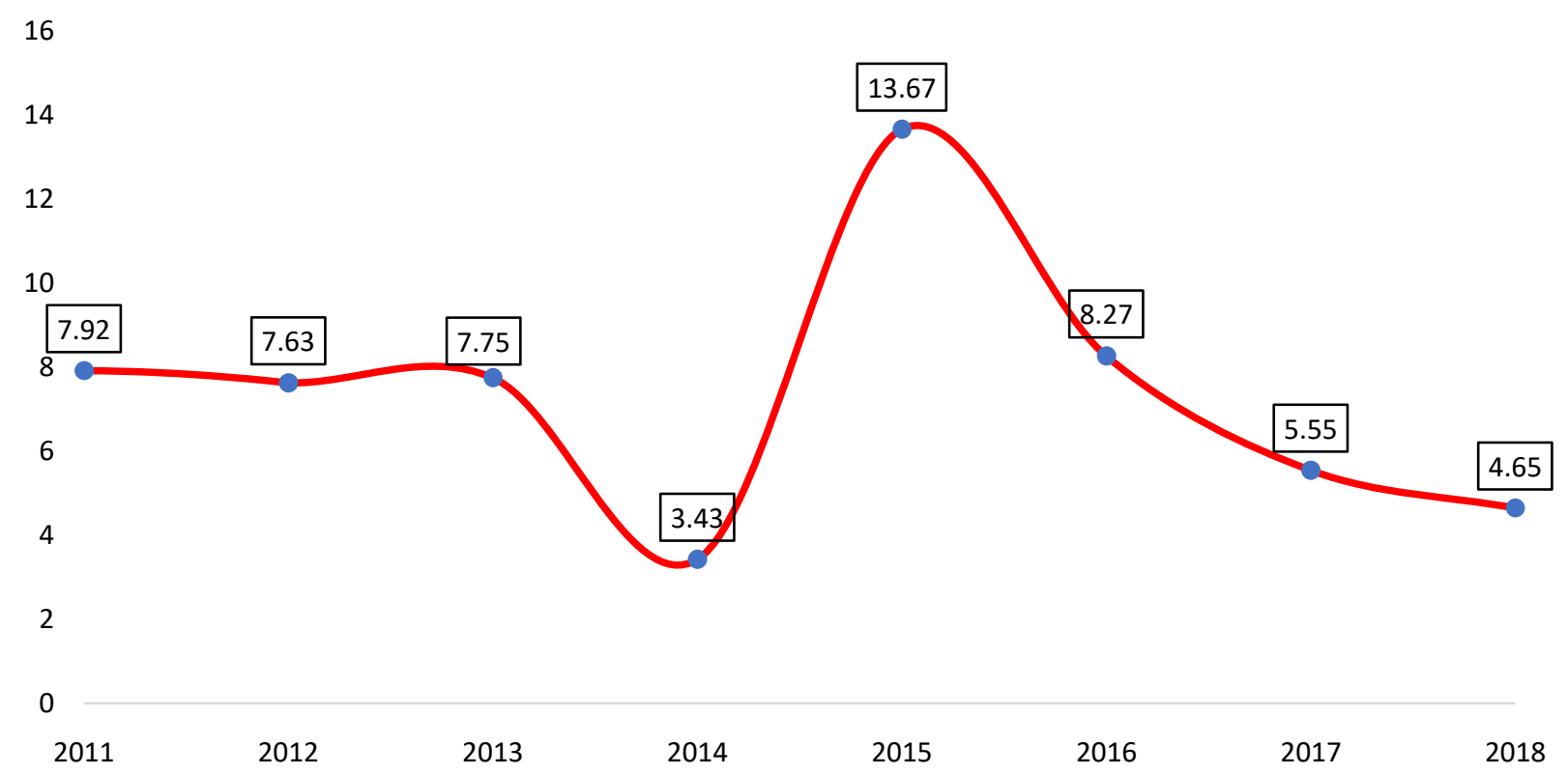

Figure 1 - GRDP per capita growth (percent) in 2011-2018 (Source: Processed data, 2019)

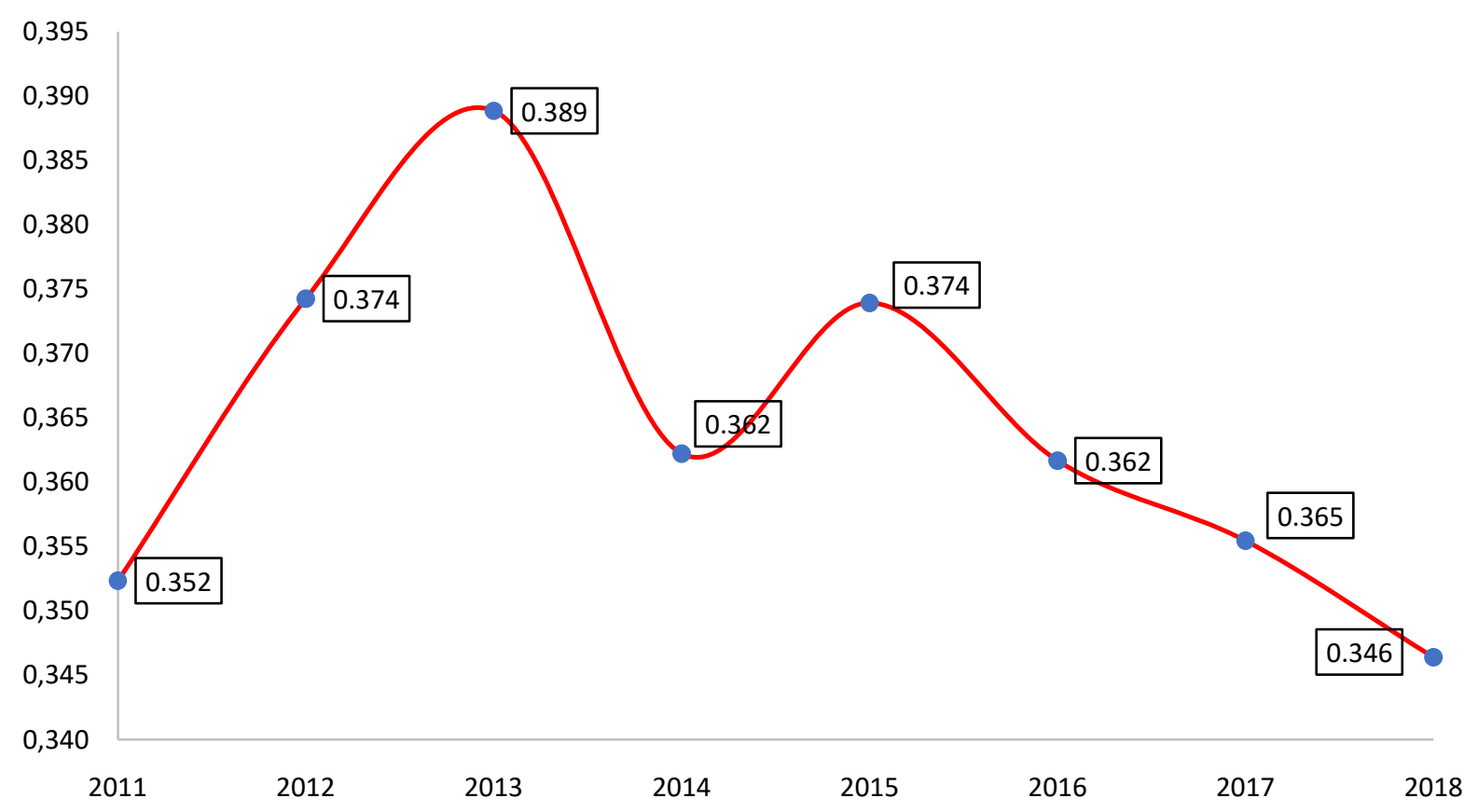

Figure 2 - Gini Ratio in 2011-2018 (Source: Processed data, 2019)

In recent years the Central Sulawesi Gini index has become a concern of academics and politicians. This is caused by the understanding that the greater or wider the index, it means that low-income groups are slower to achieve a more established life. On the other hand, the well established continue to get richer in a quick manner. This opinion has concerned the politicians in Central Sulawesi about the great risk of inequality and injustice. The most serious risk is chaos. Conflicting background of intolerance arises due to social and economic inequality. On the other hand, the GRDP per capita growth is expected to be able to push the Gini index to a lower level.

Based on the results of linear regression data analysis, the economic growth is exhibited through the Gross Regional Domestic Product (GRDP per capita) does not significantly affect the decrease in the Gini coefficient. This is reinforced by the low value 
of the coefficient of determination (R2) at 46 percent. The Gini coefficient value is more influenced by other factors and instead of regional economic growth. A positive b1 value (0.042) indicates that the higher GRDP per capita growth in Central Sulawesi increases individual inequality in Central Sulawesi society. This finding is very plausible as exhibited through the share of economic growth in Central Sulawesi. It is dominated by the mining sector especially Morowali Regency contribution through the mining sector and processing industry from the mining products. This generated a lack of contribution from the lower class in regional economic development. The GRDP per capita growth in Central Sulawesi is high. However, it is not balanced by income distribution. Individuals possessing low education find it increasingly difficult to access employment. The high level of economic inequality has resulted in low-income groups being unable to access basic needs and services such as food, health, and education. This is indicated by the low value of the Central Sulawesi Human Development Index (HDI) at 68.88 points, compared to the National HDI at 71.39 points. Therefore the local government must focus on overcoming this imbalance through community empowerment programs in the form of educational assistance as well as health and microenterprise. In addition, infrastructure development is required to improve access and reduce logistics costs between regions. Local governments need to involve industry players to contribute to the development of vocational and technical school curriculum. Under the partnership, it is hoped that private companies will offer training and internship opportunities for students and teachers. This reform is aimed at increasing the expertise of vocational students and further strengthening the skills of the Central Sulawesi workforce because inequality in Central Sulawesi is closely related to inequality in accessing economic opportunities and public services.

\section{CONCLUSION}

GRDP per capita growth in Central Sulawesi is always higher than the national average growth. However, it has not been able to improve the income gap between individuals in Central Sulawesi society. This is indicated by the results of a simple regression analysis which exhibited that there is no significant relationship between the GRDP per capita growth in Central Sulawesi and the decreasing Gini coefficient value. Therefore the Central Sulawesi regional government must focus on empowerment programs to increase community access to economic opportunities and public services.

\section{REFERENCES}

1. Novianto, S. \& Sudarsono, H. 2018. Analysis Of Poverty Level In Districts Cities of Central Jawa, Jurnal Ekonomi Pembangunan. Volume 16. No.1, 1-12.

2. Sari, N.P. 2018. Minimum Wage Implications and Poverty Numbers East Java Province, Jurnal Ekonomi Pembangunan, Vol.16.No. 2,116-121.

3. Timothy, A. 2014. Economists Debate: Has All the Important Stu§ Already Been Invented?", The Wall St. Journal, June 14, 2014.

4. Schumpeter, J.A. 1912. The Theory of Economic Development. CA: Tenth Printing.

5. Kuznets. 1955. Economic Growth and Income Inequality. Amer. Econ. Rev., 45(1), 1-28.

6. Baran, P.A. 1962. The Political Economy of Growth. US: Penguin Books.

7. Stiglitz, J. 2009, Report of the Commission on the Measurement of Economic Performance and Social Progress, Paris: The Commission on the Measurement of Economic Performance and Social Progress. http://www.stiglitz-sen-fitoussi.fr.

8. Deininger, K. \& Squire, L. 1996. A new data set measuring income inequality (English)". The World Bank economic review. Vol. 10, no. 3 (September 1996), 565-591.

9. Rencher, A.C. \& Schaalje, G. B. 2008. Linear Models Statistics $2^{\text {nd }}$ Edition, John and Sons, Inc, Hoboken, New Jersey.

10. Statistic of Sulawesi Tengah Province, Sulawesi Tengah Province in Figures 2011-2018, Palu, Sulawesi Tengah. 